Research article

\title{
IMMUNOLOGICAL AND PATHOLOGICAL INVESTIGATIONS OF NON-SPECIFIC REACTIVE HEPATITIS IN SHELTER DOGS
}

\author{
JABER Jose Raduan ${ }^{*}$, VELÁZQUEZ-WALLRAF Alicia S ${ }^{1}$, FARRAY David ${ }^{1}$, \\ RAVELO-GARCÍA Antonio G. ${ }^{2}$, CARRASCOSA Conrado ${ }^{1}$, \\ RODRÍGUEZ-VENTURA Myriam¹, PEREZ Jose ${ }^{3}$
}

\begin{abstract}
${ }^{1}$ Department of Morphology, Veterinary Faculty, University of Las Palmas de Gran Canaria; ${ }^{2}$ Institute for Technological Development and Innovation in Communications, University of Las Palmas de Gran Canaria; ${ }^{3}$ Department of Anatomía y Anatomía Patológica Comparada, Veterinary College, University of Cordoba
\end{abstract}

(Received 05 January, Accepted 05 March 2019)

\begin{abstract}
The aim of this study was to describe the gross, histopathological and immunohistochemical features of non-specific reactive hepatitis (NSRH) in stray dogs. To perform this study the livers of 23 dogs of different breed and sex were used. The tissue sections were stained with hematoxylin-eosin, and immunohistochemically. The results of this work showed that NSRH was characterized by the infiltration of lymphocytes and plasma cells scattered throughout the liver parenchyma and in the portal stroma, and associated with inflammatory and non-inflammatory diseases in other organ systems. The inflammatory infiltrate of NSRH was composed of CD3+ T lymphocytes and HLA-DR+ lymphocytes, as well as IgG+ plasma cells and alpha-1antitrypsin+ macrophages in the portal spaces and hepatic sinusoids.
\end{abstract}

Key words: liver, hepatitis, immunohistochemistry, dog

\section{INTRODUCTION}

Hepatitis in dogs has been classified as acute or chronic hepatitis [1]. Acute hepatitis is characterized by random distribution of necrosis and apoptosis, with neutrophil accumulation and minimal infiltration of lymphocytes. This type of hepatitis is usually related to infectious organisms such as viruses or bacteria [1,2]. Chronic hepatitis is the most common form, which is characterized by fibrosis, accumulation of mononuclear inflammatory cells, including lymphocytes, macrophages and plasma cells, and frequently regeneration [1-3]. Chronic liver disease may develop following chronic bile duct obstruction, infection with agents, hereditary metabolic diseases, drug-induced, or possibly autoimmune in origin [1-4].

Non-Specific Reactive Hepatitis (NSRH) is a different form of hepatitis well described in humans [5], but little is known in domestic mammals [3,6]. NSRH can be distributed

*Corresponding author: e-mail: joseraduan.jaber@ulpgc.es 
throughout the liver parenchyma in response to different systemic illnesses, most often in the gastrointestinal tract or as the residuum of prior liver inflammation. Typically, there is a mild inflammatory infiltrate in the portal tract and possibly the parenchyma without evidence of necrosis [5-6]. NSRH can be further classified into two different types according with the nature of inflammatory infiltrate; when there is an infiltrate of neutrophils within the connective tissue of the portal tracts it is called nonspecific chronic reactive active hepatitis; whereas when mononuclear cells, primarily lymphocytes and plasma cells, are presents it is termed as non-specific chronic reactive hepatitis $[2,5]$.

To date, only a sparse number of studies have been reported on this new entity in veterinary medicine [7-9]. To the author's knowledge, the composition of the cellular infiltrate observed in NSRH has not been studied in dogs. Therefore, the purpose of this study was to examine the histological findings and distribution of CD3+ $\mathrm{T}$ lymphocytes, IgG-bearing plasma cells, HLA-DR, alpha-1-antitrypsin and S-100 protein in dogs with NSRH.

\section{MATERIAL AND METHODS}

A total of 104 dogs, coming from rescue shelters of Andalucia (Spain), were necropsied at the Faculty of Veterinary Medicine of Cordoba University between 2011 and 2016. Macroscopic and microscopic examination were done on a range of organs, including the liver. The study was conducted with authorization of the Spanish Ministry of Interior (Protocol 2012) and the control of the Ethical Commission of Veterinary Medicine of the University of Las Palmas de Gran Canaria (agreement MV-2017/05).

Of these 104 carcasses, 58 cases were selected due to evidence of macroscopic or microscopic liver changes noted in the reports. Cases with moderate to severe histologic distortion due to autolysis were eliminated. After review, only 23 cases of different breed, age and sex that fit the selection criteria were included in this study (see Table 1). These criteria were used in other studies performed in marine and terrestrial mammals [6-8], and included mild liver enlargement and presence of inflammatory infiltrates in the liver parenchyma. The liver samples were fixed in 10\% neutral-buffered formalin, dehydrated through graded alcohols and embedded in paraffin wax. Sections $(4 \mu \mathrm{m}$ thick) were cut and stained with haematoxylin and eosin stain for histopathological examination. The number of inflammatory cells observed in the liver parenchyma was counted in 10 randomly selected fields of 400x magnification, including sinusoids and portal areas. NSRH was classified as mild (cell counts ranging from 20 to 50 cells per field), moderate (50 to 75 cells per field) or severe (more than 75 cells per field), following the WSAVA guidelines for liver inflammation [9]. In addition, diagnoses of extrahepatic causes in dogs with different NSRH severities were evaluated to see the relation with the degree of NSRH diagnosed. 
Table 1. Age, sex and species of dogs included in the study

\begin{tabular}{|c|c|c|c|}
\hline Case & Age & Sex & Breed \\
\hline 1 & Adult & $\mathrm{M}$ & Mixed-breed \\
\hline 2 & Young & M & Mixed-breed \\
\hline 3 & Young & M & French bulldog \\
\hline 4 & Adult & M & Golden retriver \\
\hline 5 & Young & $\mathrm{F}$ & Mixed-breed \\
\hline 6 & Adult & $\mathrm{F}$ & Yorkshire terrier \\
\hline 7 & Adult & M & Yorkshire terrier \\
\hline 8 & Young & $\mathrm{F}$ & Spanish Water Dog \\
\hline 9 & Young & $\mathrm{F}$ & Mixed-breed \\
\hline 10 & Adult & M & Mixed-breed \\
\hline 11 & Adult & $\mathrm{F}$ & Mixed-breed \\
\hline 12 & Adult & $\mathrm{F}$ & Boxer \\
\hline 13 & Young & M & Canary mastiff \\
\hline 14 & Young & M & Neapolitan mastiff \\
\hline 15 & Adult & M & Mixed-breed \\
\hline 16 & Young & $\mathrm{M}$ & Mixed-breed \\
\hline 17 & Young & M & English bulldog \\
\hline 18 & Young & $\mathrm{F}$ & Mixed-breed \\
\hline 19 & Adult & $\mathrm{F}$ & Mixed-breed \\
\hline 20 & Young & $\mathrm{F}$ & Mixed-breed \\
\hline 21 & Adult & M & Labrador retriver \\
\hline 22 & Adult & M & Mixed-breed \\
\hline 23 & Adult & $\mathrm{F}$ & Mixed-breed \\
\hline
\end{tabular}

For the immunohistochemical study only 10 liver samples were used. The avidinbiotin-peroxidase (ABC) method described elsewhere was used [8]. Several dilutions of primary and secondary antibodies, and different antigen retrieval methods were used to obtain the optimal working conditions for each antibody (Table 2). After antigen retrieval, tissue sections were rinsed (3 x $10 \mathrm{~min}$ ) in phosphate-buffered saline (PBS) $0.01 \mathrm{M} \mathrm{pH} 7.2$ and incubated with 10\% normal goat serum (Vector Laboratories, Burlingame, CA, USA) for $30 \mathrm{~min}$ at room temperature $\left(20-25^{\circ} \mathrm{C}\right)$ to block unspecific staining. After three 10-min rinses in PBS, a biotinylated goat antirabbit immunoglobulin G diluted 1 in 3000 in PBS (Vector Laboratories, Burlingame, CA, USA) was applied for $30 \mathrm{~min}$ as the secondary reagent for the primary polyclonal antibodies (pAbs), and a biotinylated goat anti-mouse immuno-globulins diluted 1 in 50 in PBS (Dako) was applied for $30 \mathrm{~min}$ as the secondary reagent for the primary monoclonal antibodies (mAbs). An ABC complex (Vector) diluted 1 in 50 in PBS was applied as the third reagent. Then, tissue sections were incubated with Vector Novared 
(Vector) according to the manufacturer's instructions. Finally, sections were rinsed in tap water, lightly counterstained with Mayer's haematoxylin, and mounted with DPX (Sigma). As negative controls, the specific primary antibodies were substituted by PBS, or rabbit or mouse non-immune serum. Dogs and rabbit mesenteric lymph node tissue sections were used as positive controls.

Table 2. Details of the primary antibodies used in this study

\begin{tabular}{lllc}
\hline Antibody & Origin & Treatment & Dilution \\
\hline $\mathrm{CD} 3+(\mathrm{pAb})$ & Rabbit & Citric acid $\dagger$ & $1 / 200$ \\
$\mathrm{IgG}(\mathrm{pAb})$ & Rabbit & Pronase* & $1 / 3000$ \\
$\mathrm{~S}-100$ protein $(\mathrm{pAb})$ & Rabbit & - & $1 / 200$ \\
$\mathrm{HLA}-\mathrm{DR}(\mathrm{mAb})$ & Mouse & Citric acid $\dagger$ & $1 / 50$ \\
$\mathrm{~A} 1 \mathrm{AT}(\mathrm{pAb})$ & Rabbit & Citric acid $\dagger$ & $1 / 3000$ \\
\hline
\end{tabular}

$\mathrm{pAb}$, polyclonal antibody; $\mathrm{mAb}$, monoclonal antibody.

$* 0.01 \%$ Pronase (Sigma Chemicals, St Louis, MO, USA) for $10 \mathrm{~min}$ at room temperature.

t0.01 M citric acid in microwave at $100^{\circ} \mathrm{C}$ for $7 \mathrm{~min}$. All antibodies supplied by Dako, Glostrup, Denmark

Immunolabelled sections obtained with the specific antibodies were evaluated with a photomicroscope and the density of immunolabelled cells was counted by two pathologists in 10 fields at x 640 magnification; the results were expressed as follows: -, negative; +, 0-5 cells per field;,$++ 5-10$ cells;,$+++ 10-20$ cells;,$++++>20$ cells.

For the statistical analysis, variables were summarized as frequencies and percentages in each extrahepatic disease. Chi-squared test $\left(\chi^{2}\right)$ with Yates correction was used to compare prevalence between age (adult /young) or sex, as well as among degree groups (mild/moderate/severe) in the set of studied diseases. Differences were considered significant at $\mathrm{p}<0.05$.

\section{RESULTS}

Grossly, the liver of 23 examined dogs appeared mildly enlarged. Histological examination revealed that all the dogs showed non-specific chronic reactive hepatitis, without the presence of the active form of NSRH. Two out of 23 dogs were diagnosed as severe, five out of 23 as moderate and the remaining sixteen dogs as mild NSRH. The histological appearance of this process in the different degrees was characterized by an inflammatory infiltrate composed of plasma cells and lymphocytes in both the stroma of the portal areas, around the hepatic veins and within the sinusoids, without evidence of hepatocellular necrosis or fibrosis. Those dogs with severe NSRH also showed marked dilatation of the hepatic sinusoids as a result of the increased number of erythrocytes, lymphocytes and plasma cells (Figure 1). 

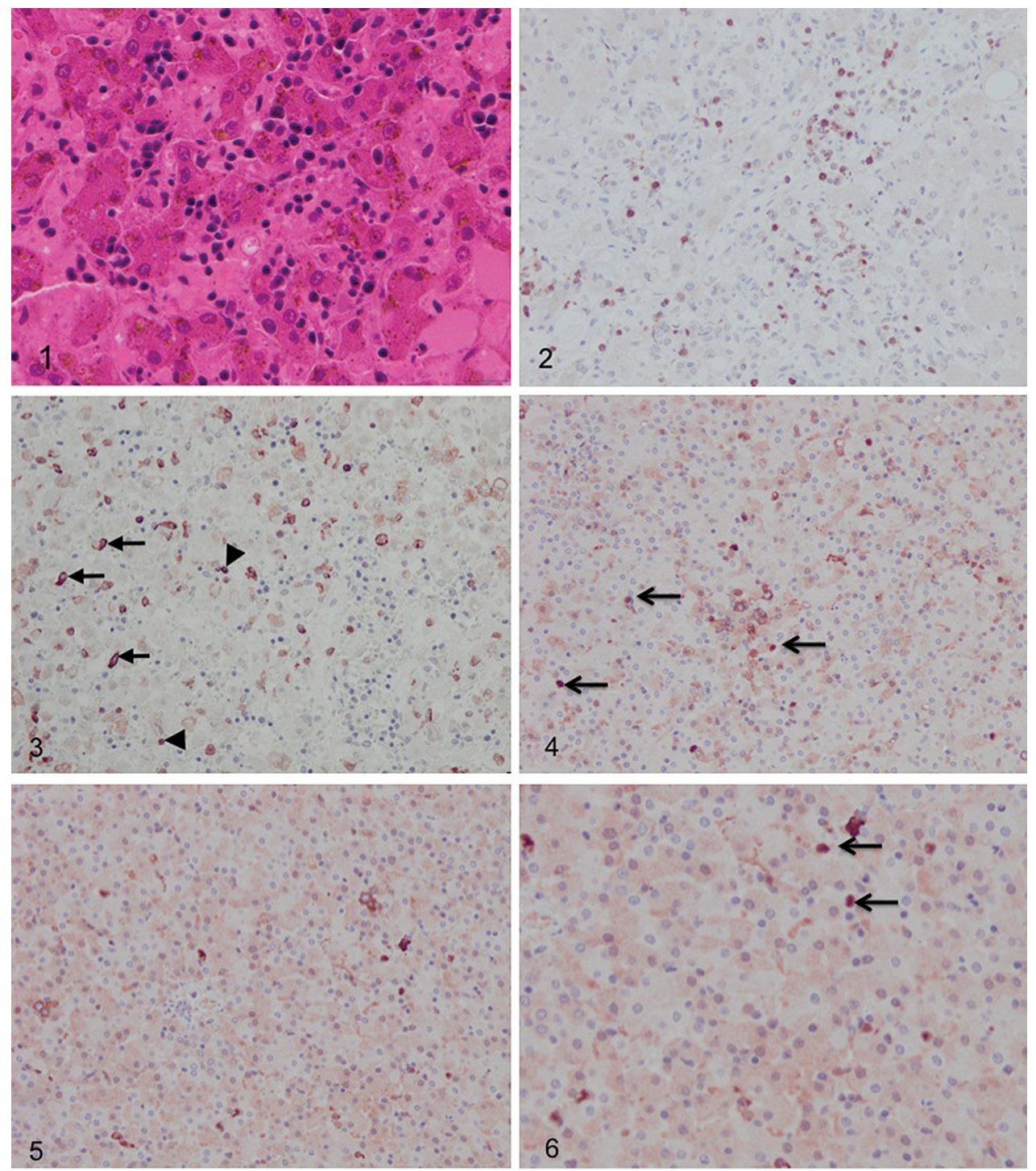

Figure 1-6: 1) Liver of mixed-breed dog, severe NSRH with inflammatory infiltrates in the hepatic sinusoids, where clusters of lymphocytes and plasma cells are identified. HE x40. 2) Liver of mixedbreed dog, showing numerous CD3 $+\mathrm{T}$ lymphocytes in the inflammatory infiltrate located in portal septa and within sinusoids. ABC method, Haematoxylin counterstain. x200. 3) Liver of mixed-breed dog, showing numerous HLRA+ macrophages (arrows) and fewer lymphocytes (arrowheads) within sinusoids. ABC method, Haematoxylin counterstain. x200. 4) Liver showing numerous alpha-1 antitrypsin+ macrophages (arrows) within sinusoids. ABC method, Haematoxylin counterstain. x200. 5) Liver showing scattered IgG+ plasma cells within sinusoids. ABC method, Haematoxylin counterstain. x200. 6) Detail of IgG+ plasma cells (arrows) within sinusoids. ABC method, Haematoxylin counterstain.

Dogs affected with NSRH showed other pre-existing extrahepatic pathologies that could have accounted for the process reported in the present work (Table 3). 
Table 3. Samples studied and overall prevalence of extrahepatic diseases in dogs

\begin{tabular}{|c|c|c|c|c|c|c|c|c|}
\hline \multirow{2}{*}{$\begin{array}{l}\text { Extrahepatic } \\
\text { diseases }\end{array}$} & \multicolumn{2}{|c|}{ Age } & \multicolumn{2}{|c|}{ Sex } & \multicolumn{3}{|c|}{ Degree } & \multirow[b]{2}{*}{$\begin{array}{c}\text { Moderate } \\
\text { - Severe } \\
(n=7)\end{array}$} \\
\hline & $\begin{array}{l}\text { Adult } \\
(n=12)\end{array}$ & $\begin{array}{l}\text { Young } \\
(\mathrm{n}=11)\end{array}$ & $\begin{array}{c}\text { Male } \\
(n=13)\end{array}$ & $\begin{array}{c}\text { Female } \\
(n=10)\end{array}$ & $\begin{array}{c}\text { Mild } \\
(\mathrm{n}=16)\end{array}$ & $\begin{array}{c}\text { Moderate } \\
(n=5)\end{array}$ & $\begin{array}{l}\text { Severe } \\
(n=2)\end{array}$ & \\
\hline Fungal granulomas & $\begin{array}{l}8.3 \% \\
(\mathrm{n}=1)\end{array}$ & & $\begin{array}{l}7.7 \% \\
(\mathrm{n}=1)\end{array}$ & & $\begin{array}{l}6.3 \% \\
(n=1)\end{array}$ & & & \\
\hline Adenovirus & $\begin{array}{l}8.3 \% \\
(\mathrm{n}=1)\end{array}$ & $\begin{array}{l}9.1 \% \\
(\mathrm{n}=1)\end{array}$ & $\begin{array}{l}7.7 \% \\
(\mathrm{n}=1)\end{array}$ & $\begin{array}{l}10 \% \\
(\mathrm{n}=1)\end{array}$ & & $\begin{array}{l}40 \% \\
(n=2)\end{array}$ & & $\begin{array}{c}28.57 \% \\
(n=2)\end{array}$ \\
\hline Virus infection & & $\begin{array}{l}9.1 \% \\
(\mathrm{n}=1)\end{array}$ & $\begin{array}{l}7.7 \% \\
(\mathrm{n}=1)\end{array}$ & & & & $\begin{array}{l}50 \% \\
(\mathrm{n}=1)\end{array}$ & $\begin{array}{l}14.3 \% \\
(\mathrm{n}=1)\end{array}$ \\
\hline Inmunodeficiency & & $\begin{array}{l}9.1 \% \\
(\mathrm{n}=1)\end{array}$ & & $\begin{array}{l}10 \% \\
(\mathrm{n}=1)\end{array}$ & $\begin{array}{l}6.3 \% \\
(\mathrm{n}=1)\end{array}$ & & & \\
\hline $\begin{array}{l}\text { Gastrointestinal } \\
\text { disease }\end{array}$ & $\begin{array}{l}33.3 \% \\
(\mathrm{n}=4)\end{array}$ & $\begin{array}{l}54.6 \% \\
(\mathrm{n}=6)\end{array}$ & $\begin{array}{l}38.5 \% \\
(\mathrm{n}=6)\end{array}$ & $\begin{array}{l}40 \% \\
(n=4)\end{array}$ & $\begin{array}{l}43.7 \% \\
(n=7)\end{array}$ & $\begin{array}{l}40 \% \\
(n=2)\end{array}$ & $\begin{array}{l}50 \% \\
(\mathrm{n}=1)\end{array}$ & $\begin{array}{l}42.9 \% \\
(n=3)\end{array}$ \\
\hline Nematodes & $\begin{array}{l}8.3 \% \\
(\mathrm{n}=1)\end{array}$ & $\begin{array}{l}18.2 \% \\
(\mathrm{n}=2)\end{array}$ & $\begin{array}{l}15.4 \% \\
(\mathrm{n}=2)\end{array}$ & $\begin{array}{l}10 \% \\
(\mathrm{n}=1)\end{array}$ & $\begin{array}{l}12.5 \% \\
(\mathrm{n}=2)\end{array}$ & $\begin{array}{l}20 \% \\
(n=1)\end{array}$ & & $\begin{array}{l}14.3 \% \\
(\mathrm{n}=1)\end{array}$ \\
\hline Parvovirus & & $\begin{array}{l}18.2 \% \\
(\mathrm{n}=2)\end{array}$ & $\begin{array}{l}7.7 \% \\
(\mathrm{n}=1)\end{array}$ & $\begin{array}{l}10 \% \\
(\mathrm{n}=1)\end{array}$ & $\begin{array}{l}12.5 \% \\
(\mathrm{n}=2)\end{array}$ & & & \\
\hline Others & $\begin{array}{r}25 \% \\
(\mathrm{n}=3)\end{array}$ & $\begin{array}{l}18.2 \% \\
(\mathrm{n}=2)\end{array}$ & $\begin{array}{l}23.1 \% \\
(\mathrm{n}=3)\end{array}$ & $\begin{array}{l}20 \% \\
(\mathrm{n}=2)\end{array}$ & $\begin{array}{c}18.75 \% \\
(\mathrm{n}=3)\end{array}$ & $\begin{array}{l}20 \% \\
(\mathrm{n}=1)\end{array}$ & $\begin{array}{l}50 \% \\
(\mathrm{n}=1)\end{array}$ & $\begin{array}{c}28.57 \% \\
(\mathrm{n}=2)\end{array}$ \\
\hline Renal disease & $\begin{array}{l}33.3 \% \\
(\mathrm{n}=4)\end{array}$ & $\begin{array}{l}9.1 \% \\
(\mathrm{n}=1)\end{array}$ & $\begin{array}{l}15.4 \% \\
(\mathrm{n}=2)\end{array}$ & $\begin{array}{l}30 \% \\
(\mathrm{n}=3)\end{array}$ & $\begin{array}{l}25 \% \\
(\mathrm{n}=4)\end{array}$ & $\begin{array}{l}20 \% \\
(\mathrm{n}=1)\end{array}$ & & $\begin{array}{l}14.3 \% \\
(\mathrm{n}=1)\end{array}$ \\
\hline Heart failure & & $\begin{array}{l}9.1 \% \\
(\mathrm{n}=1)\end{array}$ & $\begin{array}{l}7.7 \% \\
(\mathrm{n}=1)\end{array}$ & & $\begin{array}{l}6.3 \% \\
(\mathrm{n}=1)\end{array}$ & & & \\
\hline Meningitis & & $\begin{array}{l}9.1 \% \\
(\mathrm{n}=1)\end{array}$ & $\begin{array}{l}7.7 \% \\
(\mathrm{n}=1)\end{array}$ & & $\begin{array}{l}6.3 \% \\
(n=1)\end{array}$ & & & \\
\hline $\begin{array}{l}\text { Foreign body } \\
\text { obstruction }\end{array}$ & $\begin{array}{l}8.3 \% \\
(\mathrm{n}=1)\end{array}$ & & $\begin{array}{l}7.7 \% \\
(\mathrm{n}=1)\end{array}$ & & $\begin{array}{l}6.3 \% \\
(\mathrm{n}=1)\end{array}$ & & & \\
\hline Demodicosis & & $\begin{array}{l}9.1 \% \\
(n=1)\end{array}$ & $\begin{array}{l}7.7 \% \\
(n=1)\end{array}$ & & $\begin{array}{l}6.3 \% \\
(n=1)\end{array}$ & & & \\
\hline Morbillivirus & & $\begin{array}{l}9.1 \% \\
(\mathrm{n}=1)\end{array}$ & & $\begin{array}{l}10 \% \\
(\mathrm{n}=1)\end{array}$ & & $\begin{array}{l}20 \% \\
(n=1)\end{array}$ & & $\begin{array}{l}14.3 \% \\
(n=1)\end{array}$ \\
\hline Pneumonia & $\begin{array}{l}8.3 \% \\
(n=1)\end{array}$ & $\begin{array}{l}9.1 \% \\
(n=1)\end{array}$ & $\begin{array}{l}7.7 \% \\
(n=1)\end{array}$ & $\begin{array}{l}10 \% \\
(\mathrm{n}=1)\end{array}$ & $\begin{array}{l}6.3 \% \\
(n=1)\end{array}$ & $\begin{array}{l}20 \% \\
(\mathrm{n}=1)\end{array}$ & & $\begin{array}{l}14.3 \% \\
(n=1)\end{array}$ \\
\hline Peritonitis & & $\begin{array}{l}9.1 \% \\
(\mathrm{n}=1)\end{array}$ & & $\begin{array}{l}10 \% \\
(\mathrm{n}=1)\end{array}$ & & $\begin{array}{l}20 \% \\
(\mathrm{n}=1)\end{array}$ & & $\begin{array}{l}14.3 \% \\
(\mathrm{n}=1)\end{array}$ \\
\hline $\begin{array}{l}\text { Mycotic } \\
\text { tracheobronchitis } \\
\text { and }\end{array}$ & & $\begin{array}{l}9.1 \% \\
(\mathrm{n}=1)\end{array}$ & & $\begin{array}{l}10 \% \\
(\mathrm{n}=1)\end{array}$ & $\begin{array}{l}6.3 \% \\
(n=1)\end{array}$ & & & \\
\hline $\begin{array}{l}\text { Ehrlichia canis } \\
\text { infection }\end{array}$ & $\begin{array}{l}8.3 \% \\
(n=1)\end{array}$ & & $\begin{array}{l}7.7 \% \\
(n=1)\end{array}$ & & & & $\begin{array}{l}50 \% \\
(\mathrm{n}=1)\end{array}$ & $\begin{array}{l}14.3 \% \\
(n=1)\end{array}$ \\
\hline Cirrhosis & $\begin{array}{l}8.3 \% \\
(\mathrm{n}=1)\end{array}$ & & $\begin{array}{l}7.7 \% \\
(n=1)\end{array}$ & & $\begin{array}{l}6.3 \% \\
(\mathrm{n}=1)\end{array}$ & & & \\
\hline Melanoma & $\begin{array}{l}8.3 \% \\
(\mathrm{n}=1)\end{array}$ & & & $\begin{array}{l}10 \% \\
(\mathrm{n}=1)\end{array}$ & $\begin{array}{l}6.3 \% \\
(n=1)\end{array}$ & & & \\
\hline
\end{tabular}


Gastrointestinal diseases produced by parasites and viruses were the most common observed pathologies (10/23), being Ascaris spp. and Ancylostoma spp. the parasites more frequently observed $(3 / 23,13.04 \%)$, whereas canine parvovirus $(2 / 23,8.7 \%)$ was the only virus related to gastrointestinal processes. The remaining five cases of gastrointestinal diseases were of unknown causes. Renal disease was the second pathology more commonly identified in this study $(5 / 23,21.74 \%)$, and consisted mainly in glomerulonephritis and tubulonephritis. Bacterial pneumonia produced by Pasteurella spp. was also observed in 2/23 dogs, 8.7\%. In addition, widespread granulomas due to fungal infection (Cryptococcus neoformans) were found in 2/23 dogs, $8.7 \%$. Other viruses identified were canine adenovirus $\mathrm{I}(2 / 23,8.7 \%)$ and canine morbillivirus $(2 / 23,8.7 \%)$. Other pathologies observed in these dogs were meningitis, demodicosis, Ehrlichia canis infection, melanoma and liver cirrhosis (see Table 3).

In the statistical analysis, no differences were found between age, sex, and degree of NSRH considering $\mathrm{p}$ values significant at $\mathrm{p}<0.05$. Gastrointestinal disease was the most prevalent process, showing $\mathrm{p}$ value of 0.55 according to age, and 0.9 and 0.67 in the case of sex and degree of NSRH, respectively (see Table 3).

The immunoreactivity pattern and distribution of immunolabelled cells with CD3, IgG, S-100, HLA-DR and alpha-1-antitrypsin (A1AT) antibodies were similar in the control dog liver, and mouse and rabbit lymph nodes. Results of the imunohistochemical study of control liver and hepatic distribution of immunolabelled cells at different degrees of NSRH are summarized in Table 4.

Table 4. Distribution of immunoreactive cells in NSRH

\begin{tabular}{clccccc}
\hline $\begin{array}{c}\text { Antibodies } \\
\text { cases }\end{array}$ & $\begin{array}{l}\text { Degree } \\
\text { NSRH }\end{array}$ & CD3+ & IgG & HLA-DR & A1AT & S100 \\
\hline 1 & Moderate & + & + & $++++(+)$ & + & + \\
2 & Moderate & ++++ & +++ & ++++ & ++ & + \\
3 & Severe & + & ++++ & + & ++ & + \\
4 & Mild & ++ & + & ND & ++ & + \\
5 & Moderate & + & ++ & ++ & + & + \\
6 & Moderate & + & +++ & ++++ & + & + \\
7 & Mild & + & + & ++++ & +++ & + \\
8 & Mild & +++ & ++++ & $++++(+)$ & +++ & + \\
9 & Severe & + & +++ & ND & +++ & + \\
10 & Mild & + & ++ & +++ & ++ & + \\
\hline
\end{tabular}

Reaction between antibodies and cells were classified as very mild $(+,<5$ cells), mild $(++, 5-10$ cells), moderate $(+++, 10-20$ cells) and intense $(++++,>20$ cells); ND: Not done. 
In the control livers only occasional lymphocytes in the portal areas or within hepatic sinusoids were positive with the anti-CD3 pAb and the HLA-DR mAb. In addition, HLA-DR mAb yielded a diffuse nuclear and cytoplasmic immunoreactivity in small numbers of dendritic-like cells in portal spaces. However, macrophages, as well as Kuppfer cells and circulating monocytes did not show immunoreactivity against A1AT and S100 pAbs.

Non-specific chronic reactive hepatitis was characterized by an abundant number of $\mathrm{CD}^{+}{ }^{+} \mathrm{T}$ lymphocytes (Figure 2) and HLA-DR lymphocytes (Figure 3) located both in the hepatic parenchyma and in portal areas. Small numbers of lymphocytes and macrophages located in the portal areas and hepatic sinusoids were $\mathrm{S}-100+$, whereas, A1AT- macrophages were strongly increased compared to the control livers (Figure 4). A similar increase was observed in stellate cells and macrophages located in portal space and sinusoids that showed strong immunoreactivity with HLA-DR pAb (Figure $3)$. In these lesions, numerous plasma cells showed strong immunoreactivity with the anti-IgG pAb (Figures 5-6).

\section{DISCUSSION}

The histologic findings observed in the group of 23 dogs studied were similar to those cases of NSRH described in dolphins and whales stranded in the Canary Archipelago [7-8], dogs [6] and large studies of humans affected with the hepatitis $C$ virus [10]. Therefore, non-specific reactive hepatitis was the hepatic process observed in the dogs of this study. However, this form of hepatitis is often not taken in consideration, and misdiagnosed as chronic hepatitis. NSRH may result from a variety of causes, such as bacterial endotoxins resulting from sepsis or increased gastrointestinal absorption, or a bystander reaction of the liver to any systemic reaction, as well as febrile illnesses and inflammation in the splachnic bed [3,5-8].

In our study, non-specific chronic reactive hepatitis was the unique form of NSRH detected in these dogs. These animals were distributed throughout the different age, sex and breed groups of the study population, and often associated $(17 / 23,73.91 \%)$ with chronic inflammatory lesions in other organ systems, most commonly gastrointestinal disease (10 cases), renal disease (5 cases) or pneumonia (2 cases). Similar results were seen in other studies performed in dogs $[3,6]$. Nevertheless, other form of NSRH termed as non-specific reactive active hepatitis was observed in other study done in cetaceans [8], although it was not seen in any of the dogs of the present work.

The most of the examined dogs had mild portal inflammatory infiltrates $(16 / 23$, $69.57 \%$ ). This pattern was also a common finding in a case series of hepatic lesions conducted in cetaceans [7-8], as well as in dogs [6]. In contrast, 2 out of 23 dogs of the present study showed severe inflammatory infiltrate in the hepatic sinusoids forming clusters. It has been suggested that NSRH could be associated with residual hepatic inflammation, diseases with fever or systemic inflammation [5,9], although $3 / 23$ of the 
dogs had no other significant inflammatory disease seen on necropsy. In other studies, done in large series of marine mammals, NSRH was found in combination with other hepatic findings such as lipidosis or peracute hepatitis [4]. However, this type of hepatic findings was not described in any dog in our study. Only one dog out of 23 showed liver cirrhosis that could be related to exposure to toxic substances or viruses. Moderate $(5 / 23,21,74 \%)$ and severe $(2 / 23,8,7 \%)$ NSRH were often associated with inflammatory and non-inflammatory diseases in other organ systems. Nevertheless, cases with mild inflammatory infiltrates were associated with gastrointestinal and renal disease, pneumonia, and other pathologies like melanoma, dermatitis, Ehrlichia canis infection or meningitis.

This is the first study describing the expression of CD3 + T lymphocytes, IgG-bearing plasma cells, HLA-DR, alpha-1-antitrypsin and S-100 protein in dogs affected with NSRH. The immunolabelling obtained with antibodies against rabbit CD3, IgG, S-100 protein and mouse HLA-DR in dog lymph node tissue sections was quite similar to that observed in other reports using analogous antibodies [11-12]. However, A1AT showed strong immunoreaction by macrophages in the dog liver and lymph node tissue sections. This is of interest because human A1AT did not succeed to yield immunoreaction in macrophages of dolphin liver and lymph node tissue sections despite the use of different dilutions and antigen retrieval methods [12]. This discrepancy could be due to different macrophage activation in both studies, to the effect of tissue fixation, or to better cross-reactivity of mouse A1AT antibody with dog antigens. Further studies are required to clarify this matter.

Non-specific chronic reactive hepatitis in dogs was characterized by the infiltrate of an abundant number of $\mathrm{CD}^{+} \mathrm{T}$ lymphocytes and $\mathrm{IgG}^{+}$plasma cells within hepatic sinusoids and portal spaces. This cellular distribution and inflammatory infiltrates were identified in other mammalian species with similar process $[4,12]$. However, only a sparse number of $\mathrm{CD}^{+} \mathrm{T}$ lymphocytes, primarily observed in portal spaces were seen in common dolphins [12]. This difference could be related to the different stage of inflammation observed in these animals.

The numerous lymphocytes expressing HLA-DR antigen found in dogs with different degree of NSRH, both in the hepatic inflammatory infiltrate and in the control lymph nodes, were quite similar to those reported in other mammals using MHC class II, such as the pig, both in lymph nodes [13] and in the hepatic inflammatory infiltrate associated with Ascaris sum infection [11]. These results could suggest T cells activation as happens in dolphins [14], and whales [15]. Nonetheless, the presence of stellate cells varied depending on the pre-existing extra or intrahepatic disease that could have accounted for the process studied. Similar findings have been reported in other studies performed in dolphins [12], and cats [16].

Interestingly, no information has been reported about NSRH in stray dogs, among which parasitic infestations [17], bacterial infections [18], and viruses, such as those that affect the digestive system have been frequently described [19]. Furthermore, a recent 
study highlighted the importance to study stray dogs since can have an epidemiological significance in relation to zoonotic diseases [20].

In conclusion, non-specific chronic reactive hepatitis was the only form of reactive hepatitis observed in dogs in the present study and was often associated with inflammatory and non-inflammatory diseases in other organ systems. This type of hepatitis was characterized by high numbers of lymphocytes expressing HLA-DR and CD3, as well as $\mathrm{IgG}^{+}$plasma cells and alpha-1-antitrypsin macrophages. All used antibodies in this study were found suitable for immunohistochemical studies on formalin-fixed tissues of dogs with NSRH.

\section{Acknowledgments}

We thank Marisa Mohamad and Jamal Jaber for their constructive comments, as well as Nathalie Wallraf and Alfonso Velázquez for their unconditional support. This work was funded in part by Consejeria de Educación, Cultura y Deportes del Gobierno de Canarias (Pi 2005/170).

\section{Authors' contributions}

JJR and PJ conceived the study, and participated in its design and coordination and helped to draft the manuscript. JJR, VWA and PJ carried out the histological study. RGA, CC and RVM participated in the design of the study and performed the statistical analysis. All authors read and approved the final manuscript.

\section{Declaration of conflicting interests}

The author(s) declared no potential conflicts of interest with respect to the research, authorship, and/or publication of this article.

\section{Statement of Informed Consent}

The owner understood procedure and agrees that results related to investigation or treatment of their companion animals could be published in this journal.

\section{REFERENCES}

1. Cullen J: Liver, Biliary System, and Exocrine Pancreas. In McGavin M., Zachary J. (Eds.). Pathologic Basis of Veterinary Disease. 4th edition. St. Louis, Missouri: Mosby, Elsevier; 2007, 393-461.

2. Cullen J, Stalker M: Liver and Biliary System. In Jubb K., Kennedy P., Palmer N. (Eds.) Pathology of domestic animals. 6th edition. Volume 2. San Diego, California: Academic Press Inc; 2016, 258-352. 
3. Rothuizen J, Van Den Ingh TSGAM: Hepatitis in dogs: A review. Tijdschr Diergeneeskd 1998, 123: 246-252.

4. Hiemstra S, Harkema L, Wiersma LCM, Keesler RI: Beyond parasitism: Hepatic Lesions in Stranded Harbor Porpoises (Phocoena phocoena) without trematode (Campula oblonga) infection. Vet Pathol 2015, 51: 1174-1182.

5. MacSween RNM: Pathology of the liver. 4th ed. New York: Churchill Livingstone London; $2002,828$.

6. Neumann S, Danner W: Reactive Hepatitis in dogs. Glob Vet 2012, 9: 454-459.

7. Jaber JR, Pérez J, Arbelo M, Andrada M, Hidalgo M, Gómez-Villamandos JC, Van den Ingh T, Fernández A: Hepatic lesions in cetaceans stranded in the Canary Islands. Vet Pathol 2004, 41:147-153.

8. Jaber JR, Pérez J, Carrascosa C, Carballo M, Fernández A: Non-specific reactive hepatitis in dolphins stranded in the Canary Islands. J Appl Anim Res 2013, 41: 398-403.

9. Van Den Ingh T, Cullen J, Twedt D: Morphological classification of biliary disorders of the canine and feline liver. In Rothuizen J, et al. (Eds.). WSAVA Standards for Clinical and Histological Diagnosis of Canine and Feline Liver Diseases. Philadelphia: Saunders Elsevier; 2006, 61-76.

10. Healey CJ, Chapman RW, Fleming KA: Liver histology en hepatitis C infection: a comparison between patients with persistently normal or abnormal transaminases. Gut 1995, 37: 274-278.

11. Perez J, Garcia PM, Mozos E, Bautista MJ, Carrasco L: Immunohistochemical characterization of hepatic lesions associated with migrating larvae of Ascaris suum in pigs. J Comp Pathol 2001, 124: 200-206.

12. Jaber JR, Pérez J, Arbelo M, Herráez P, Espinosa de los Monteros A, Guisado F, Fernández T, Fernández A (2003) Immunophenotypic characterization of the hepatic inflammatory cell infiltrates in common dolphins. J Comp Pathol 129: 226-230.

13. Tanimoto T, Ohtsuki Y: Evaluation of antibodies reactive with porcine lymphocytes and lymphoma cells in formalin-fixed, paraffin-embedded, antigen-retrieved tissues sections. Am J Vet Res 1996, 57: 853-859.

14. Romano TA, Ridgway SH, Quaranta V: MHC class II molecules and immunoglobulins on peripheral blood lymphocytes of the bottlenosed dolphin, Tursiops truncates. J Exp Zool 1992, 263: 96-104.

15. De Guise S, Bernier J, Martineau D, Beland P, Fournier M: Phenotyping of beluga whale blood lymphocytes using monoclonal antibodies. Dev Comp Immunol 1997, 21: 425-433.

16. Aleksić-Kovačević S, Kukolj V, Kureljušić B, Marinković D, Knežević Đ, Ignjatović I, Jovanović M, Knežević Milijana, Gledić D: Role of hepatic stellate cells (HSCs) in the development of hepatic fibrosis in cats with polycystic kidney disease (PKD). Acta Vet.Beograd 2010, 60(4): 391-400.

17. Liberato C, Berrilli F, Odorizi L, Scarcella R, Barni M, Amoruso C, Scarito A, Filippo MMD, Carvelli, A, Iacoponi F, Scaramozzino P: Parasites in stray dogs from Italy: prevalence, risk factors and management concerns. Acta Parasitol 2018 63:27-32.

18. Piratae S, Pimpjong K, Vaisusuk K, Chatan W: Molecular detection of Ehrlichia canis, Hepatozoon canis and Babesia canis vogeli in stray dogs in Mahasarakham province, Thailand. Ann Parasitol 2015, 61: 183-187. 
19. Castanheira P, Duarte A, Gil S, Cartaxeiro C, Malta M, Vieira S, Tavares S: Molecular and serological surveillance of canine enteric viruses in stray dogs from Vila do Maio, Cape Verde. BMC Vet Res 2014, 10:91.

20. Bogunović D, Stević N, Sidi-Boumedine K, Mišić D, Tomanović S, Kulišić Z, Magaš V, Radojičić S: Molecular evidence of Q fever agent Coxiella burnetii in Ixodid ticks collected from stray dogs in Belgrade (Serbia). Acta Vet.-Beograd 2018, 68(3): 257-268.

\title{
IMUNOLOŠKA I PATOMORFOLOŠKA ISPITIVANJA NESPECIFIČNOG HEPATITISA KOD PASA IZ AZILA
}

\author{
JABER Jose Raduan, VELÁZQUEZ-WALLRAF Alicia S, FARRAY David, \\ RAVELO-GARCÍA Antonio G., CARRASCOSA Conrado, \\ RODRÍGUEZ-VENTURA Myriam, PEREZ Jose
}

Cilj ove studije je bio da se opišu makroskopske, hiistopatološke i imunohistohemijske karakteristike nespecifičnog reaktivnog hepatitisa (NSRH) kod pasa lutalica. U toku ispitivanja korišćene su jetre 23 psa različitih rasa i pola. Isečci tkiva su bojeni hematoksilin-eozin bojom i imunohistohemijski. Rezultati ovog ispitivanja su pokazali da NSRH karakteriše infiltracija limfocita ima i plazma ćelijama u parenhimu jetre i u portalnoj stromi, što je udruženo i sa inflamatornim i neinflamatornim bolestima u drugim sistemima organa. Inflamatorni infiltrat NSRH-a se sastoji od CD3+ T limfocita i HLA-DR + limfocita, kao i od IgG + plazma ćelija i alfa-1-antitripsin + makrofaga u portalnom prostoru i hepatičnim sinusoidama. 